\title{
PENDIDIKAN AGAMA ISLAM DALAM MENGATASI PERILAKU HOMOSEKSUAL (GAY)
}

\author{
Nanat Fatah Natsir \\ UIN Sunan Gunung Djati Bandung \\ E-Mail: nanatfatahnatsir@uinsgd.ac.id \\ Hasbiyallah Hasbiyallah \\ UIN Sunan Gunung Djati Bandung \\ E-Mail: hasbiyallah@uinsgd.ac.id \\ Agung Alamsyah \\ UIN Sunan Gunung Djati Bandung \\ E-Mail: alamsyahagung302@gmail.com
}

\begin{tabular}{|c|c|c|}
\hline Received & Revised & Accepted \\
\hline 4 July 2019 & 2 Agustus 2019 & 20 Agustus 2019 \\
\hline
\end{tabular}

\section{THE ISLAMIS RELIGIOUS EDUCATION IN OVERCOMING HOMOSEXUALITY BEHAVIOR}

Abstract:

This study aims to explore and understand how the role of Islamic religious education in preventing and treating homosexual or gay behavior. Because there are so many homosexual actors who experience a psychological shock caused by their ignorance in dealing with the matter. The results of this study are to find out the extent to which homosexuals view the prohibition of Islam in carrying out such deviant behavior and also to find out how to overcome this deviant behavior with prevention and healing through the teachings of Islamic religious education. This study used a qualitative method with a phenomenological approach and also a study of religious studies as a solution in overcoming homosexual behavior and using five data sources in the form of five different gay resource persons. Homosexual informants realize that homosexual behavior is something that is prohibited and forbidden by religion and a way to overcome this behavior is as a prepentive effort by realizing the prohibition of this behavior in religion, leaving all associations related to homosexual behavior, realizing the danger posed by behavior 
homosexuals and provide counseling for Islamic understanding to homosexual actors while curative efforts that can be taken are by doing ruqyah syar'iyyah and also the rituals of the riyadhah of ibadah.

Key words: homosexual (gay), Islamic education

\begin{abstract}
Abstrak:
Penelitian ini bertujuan untuk menggali dan memahami bagaimana peran pendidikan agama Islam dalam mencegah dan mengobati perilaku homoseksual atau gay. Dikarenakan banyak sekali para pelaku homoseksual yang mengalami goncangan kejiwaan yang diakibatkan ketidak tahuan mereka dalam menanggulangi perihal masalah ini. Hasil penelitian ini yaitu untuk mengetahui sejauh mana pandangan para pelaku homoseksual terhadap larangan agama Islam dalam melakukan perilaku menyimpang tersebut dan juga untuk mengetahui bagaimana cara mengatasi perilaku menyimpang ini dengan upaya pencegahan dan penyembuhan melalui ajaran pendidikan agama Islam. Penelitian ini menggunakan metode kualitatif dengan pendekatan fenomenologi dan juga studi telaah agama sebagai solusi dalam mengatasi perilaku homoseksual tersebut dan menggunakan lima sumber data berupa lima narasumber gay yang berbeda-beda. Para informan homoseksual menyadari bahwa perilaku homoseksual merupakan suatu hal yang dilarang dan diharamkan oleh agama dan cara untuk mengatasi perilaku ini yaitu sebagai upaya prepentif dengan cara menyadari perihal larangan perilaku ini dalam agama, meninggalkan semua pergaulan yang berkaitan denganperilaku homoseksual, menyadari bahaya yang ditimbulkan dari perilaku homoseksual dan memberikan bimbingan konseling pemahaman keislaman kepada para pelaku homoseksual sedangkan upaya kuratif yang dapat ditempuh yaitu dengan cara melakukan ruqyah syar'iyyah dan juga ritual riyadhah ibadah.
\end{abstract}

Kata kunci: Homoseksual (gay), Pendidikan Agama Islam

\title{
Pendahuluan
}

Homoseksual atau gay merupakan suatu perilaku yang belum bisa diterima oleh masyarakat Indonesia karena dianggap tabu dan kontradiktif dengan seluruh pemahaman keagamaan terutama agama Islam sangat menolak keras perilaku menyimpang ini. Homoseksual atau gay adalah suatu orientasi seksual menyimpang yaitu seseorang yang menyukai atau mencintai sesama jenisnya sendiri. Seperti lakilaki mencintai laki-laki yang disebut dengan istilah gay (Dermawan 2016).

Dalam menjalankan perintah agama dan segala anjurannya para pelaku homoseksual atau gay ini juga tidak sedikit yang taat dalam menjalankannya, tetapi tidak sedikit pula yang meninggalkannya, bahkan keluar secara emosional dari kepercayaannya hanya untuk membebaskan diri dari segala aturan agamanya. Dengan fenomena ini membuktikan bahwasannya para pelaku homoseksual atau gay menyadari bahwasannya perilaku yang mereka lakukan adalah perbuatan yang salah bahkan fatal dalam kehidupannya. 
Ada beberapa penelitian yang membahas terkait masalah penyimpangan seksual ini salah satunya penelitian yang dilakukan oleh Okdinata dengan judul penelitian "Religiusitas Kaum Homoseks" penelitian ini membahas tentang dinamika psikologi gay atau homoseks dalam keagamaannya dan membahas tentang penerimaan diri homoseks dalam agama yang dianutnya. Adapun bahasan penelitian yang penulis lakukan tidak jauh berbeda dengan apa yang peneliti-peneliti lainnya lakukan karena memiliki subyek penelitian yang sama tetapi berbeda obyek masalah yang ditelitinya.

Ditinjau dari sudut pandang definitif homoseksual merupakan sebuah perasaan ketertarikan kepada sesama jenis dan menimbulkan sensasi rasa cinta secara berkelanjutan serta orientasi seksual yang berbeda karena cenderung menyukai sesama jenis dibanding dengan lawan jenisnya. Homoseksual atau gay ini juga dapat diartikan sebagai suatu rasa ketertarikan yang romantis dimana perilaku seksual ini diaplikasikan pada gender yang sama. Homoseksual juga mengacu pada sudut pandang seseorang tentang memaknai identitas dirinya dalam menjalanka pola hidupnya (Okdinata 2009).

Isu mengenai homoseksual ini sudah menjadi perhatian khusus bagi masyarakat dan juga pemerintah karena ditakutkan dapat mempengaruhi kualitas hidup individu gay sendiri ataupun kualitas hidup masyarakat disekelilingnya. Banyak sekali para pelaku homoseksual yang ditemukan oleh penulis yang mengungkapkan tentang berbagai masalah yang di hadapinya salah satunya mengenai ketidaknyamanannya dalam menjalankan kehidupan, perasaan dan emosi yang tidak stabil serta merasakan problematika keimanan yang dapat mengguncang jiwanya sehingga menimbulkan kegelisahan dan ketidak tenangan hidup karena merasa perilaku yang selama ini diperbuatnya bersinggungan dengan aturan agama dan melanggar ketentuan yang telah Allah Swt buat.

Tujuan yang ingin dicapai oleh penulis dalam penelitian ini yaitu untuk mengetahui sejauh mana para pelaku homoseksual atau gay dalam memahami larangan agama Islam terkait perilaku menyimpang ini dan juga untuk mengetahui bagaimana upaya atau langkah pencegahan atas perilaku penyimpangan seksual ini.

\section{Metode Penelitian}

Metode penelitian yang digunakan dalam penelitian yaitu metode kualitatif yaitu merupakan suatu metode penelitian yang berdasarkan pada filsafat postpositivisme, digunakan untuk meneliti pada kondisi obyek yang alamiah, dimana peneliti merupakan berperan sebagai instrumen kunci (Sugiyono 2017). Adapun pendekatan yang digunakan dalam penelitian ini adalah pendekatan fenomenologi dengan telaah pendidikan agama Islam dalam penyelesaian dan mengatasi masalah perilaku homoseksual sesuai dengan judul penelitian yang tertera. Pendekatan fenomenologi merupakan suatu pendekatan penelitian yang bertujuan untuk memahami dan mempelajari pengalaman hidup seseorang terkhusus gay dalam penelitian ini dan untuk teknik pengumpulan data yang digunakan oleh penulis dalam penelitian ini yaitu partisipasi Informan, observasi 
Nanat F.N., Hasbiyallah, dan Agung Alamsyah

Pendidikan Agama Islam dalam Mengatasi......

melalui media sosial dan aplikasi datting gay, dan wawancara secara khusus dan eksklusif (Alase 2017). Adapun sumber data yang digunakan dalam penelitian ini terdiri dari lima narasumber homoseksual atau gay yaitu informan DAM, UT, FI, AW, dan informan IM.

Tabel 1 Sumber Data Penelitian

\begin{tabular}{|c|c|c|c|c|c|c|}
\hline No & Informan & Usia & Profesi & $\begin{array}{c}\text { Asal } \\
\text { Daerah }\end{array}$ & $\begin{array}{c}\text { Usia } \\
\text { Menyadari }\end{array}$ & $\begin{array}{l}\text { Indikasi } \\
\text { Penyebab }\end{array}$ \\
\hline 1 & DAM & $\begin{array}{c}22 \\
\text { tahun }\end{array}$ & Mahasiswa & Ciamis & $\begin{array}{lr}\text { Sejak usia dini } \\
\text { dan } & \text { berani } \\
\text { mengungkapkan } \\
\text { pada usia } \\
\text { tahun }\end{array}$ & $\begin{array}{l}\text { Disebabkan } \\
\text { karena } \\
\text { ketimpangan } \\
\text { pola asuh atau } \\
\text { pola asuh yang } \\
\text { salah dan } \\
\text { sering bergaul } \\
\text { dengan teman } \\
\text { perempuan }\end{array}$ \\
\hline 2 & UT & $\begin{array}{l}25 \\
\text { tahun }\end{array}$ & $\begin{array}{l}\text { Mahasiswa } \\
\text { dan } \\
\text { karyawan } \\
\text { swasta di } \\
\text { perusahaan } \\
\text { tekstil }\end{array}$ & Sumedang & $\begin{array}{l}\text { Dibawah usia } 15 \\
\text { tahun dan mulai } \\
\text { berani } \\
\text { memantapkan } \\
\text { diri sebagai gay } \\
\text { pada usia } 17 \\
\text { tahun }\end{array}$ & $\begin{array}{l}\text { Selalu merasa } \\
\text { nyaman jikalau } \\
\text { ada perhatian } \\
\text { khusus dan } \\
\text { berlebih dari } \\
\text { seorang pria }\end{array}$ \\
\hline 3 & FI & $\begin{array}{l}38 \\
\text { tahun }\end{array}$ & $\begin{array}{l}\text { Pengusaha } \\
\text { wedding } \\
\text { organizer dan } \\
\text { produk- } \\
\text { produk } \\
\text { kecantikan }\end{array}$ & Bandung & $\begin{array}{lll}\text { Pada usia } & 15 \\
\text { tahun } & & \end{array}$ & $\begin{array}{l}\text { Pola asuh yang } \\
\text { tidak seimbang } \\
\text { dan pengaruh } \\
\text { teman sebaya } \\
\text { sewaktu SMA } \\
\text { yang memiliki } \\
\text { perilaku yang } \\
\text { sama }\end{array}$ \\
\hline 4 & AW & $\begin{array}{c}24 \\
\text { tahun }\end{array}$ & Apoteker & Sumedang & $\begin{array}{l}\text { Pada rentang } \\
\text { usia } 10-13 \text { tahun }\end{array}$ & $\begin{array}{l}\text { Dikarenakan } \\
\text { aspek ketidak } \\
\text { harmonisan } \\
\text { didalam } \\
\text { keluarga, } \\
\text { tekanan } \\
\text { psikologis dan } \\
\text { kekerasan dari } \\
\text { ayah }\end{array}$ \\
\hline 5 & IM & $\begin{array}{l}32 \\
\text { tahun }\end{array}$ & Perawat & Cianjur & $\begin{array}{lr}\text { Pada } & \text { usia } \\
\text { remaja dan } \\
\text { tidak thu jelas } \\
\text { pada usia berapa }\end{array}$ & \begin{tabular}{ll}
\multicolumn{2}{l}{ Ketertarikan } \\
terhadap pria \\
tampan dan \\
faktor \\
informasi yang \\
didapat dari \\
internet
\end{tabular} \\
\hline
\end{tabular}


Untuk mendapatkan hasil dari pandangan Informan terhadap larangan homoseksual dalam agama Islam ini peneliti melakukan penelitian ini di mulai dari tanggal 28 November 2018 yaitu dengan pertama-tama menemui Informan "DAM" di salah satu tempat perbelanjaan di Kota Bandung. Lalu menemui Informan "UT" di rumah kosnya di daerah Kecamatan Rancaekek pada tanggal 15 Desember 2018 dan selanjutnya peneliti menemui Informan "FI" di salah satu apartemen pribadi Informan di daerah Ciumbeuleuit Bandung pada tanggal 10 Januari 2019 dan selanjutnya peneliti juga menemui Informan "AW" di rumah kosnya di daerah Cibiru pada tanggal 20 Januari 2019 dan terakhir peneliti menemui Informan "IM" di salah satu restoran di daerah Cipanas Cianjur pada tanggal 2 Februari 2019 dan pada tanggal 25 sampai dengan tanggal 27 maret di salah satu hotel di daerah puncak Bogor. Jalur komunikasi antara Informan dan peneliti tidak berhenti pada waktu tersebut saja tetapi tetap berlangsung melakukan komunikasi melalui berbagai media sosial dengan catatan untuk mendapatkan data atau hasil penelitian yang lebih dalam.

\section{Hasil Penelitian dan Pembahasan}

Informan "DAM, UT, FI, AW dan IM" semua menyadari bahwasannya perilaku homoseksual itu merupakan hal yang sangat dilarang dan haram untuk dilakukan. Dan menyadari apa saja efek yang ditimbulkan dari perilakunya tersebut. Tetapi karena sebelumnya semua Informan mengedepankan hawa nafsu dan mengenyampingkan ajaran agama Islam semua mereka lakukan demi untuk memenuhi kebutuhan batinnya.

Semua Informan merasakan kehawatiran yang luar biasa ketika melakukan semua perilakunya karena sadar akan ketentuan hukum Islam terkait perilaku tersebut. Terkadang Informan merasa terpuruk dengan keadaannya yang mempunyai perilaku menyimpang tersebut tetapi Informan tidak tahu apa yang harus dilakukan dan bagaimana untuk mengantisipasinya. Oleh karena itu, Informan mulai membiasakan diri untuk melakukan ibadah ritual seperti shalat atau membaca ayat-ayat al-Qur'an yang bisa Informan baca dan pahami isinya dengan tujuan untuk memberikan rasa ketenangan pada pikiran dan batinnya.

Informan mengaku bahwasannya semua itu tidak mudah, karena dikala Informan merasa sendiri dan tidak ada seseorang yang bisa membimbingan Informan tersebut akan berpikiran untuk melakukan perbuatan homoseksualnya lagi tetapi dengan menyadari bahwasannya jikalau mengulang perbuatan tersebut Informan akan semakin jatuh dan terpuruk. Karena Informan sadar bahwa didalam hati kecilnya berkata didalam setiap perbuatan yang dilakukannya ada dzat yang mengawasi yaitu Allah SWT sebagai Tuhan yang maha mengawasi.

Informan juga sadar bahwa perilaku homoseksual itu merupakan perbuatan yang keji sebagaiman Informan ketahui tentang kisah kaum sodom yang Allah binasakan dan hinakan perbuatannya. Dengan sedikit pemahaman tersebut Informan merasa terproteksi untuk melakukan hal-hal yang berakitan dengan perilaku menyimpang tersebut. Dengan adanya kesadran dan pemahaman terkait 
ajaran Islam yang melarang perbuatan homoseksual kelima Informan yang peneliti teliti semua Informan perlahan meninggalkan dan berusaha untuk bertaubat dari perbuatannya. Dengan melakukan hal-hal yang bersifat positif yaitu dengan cara mempelajari dan memperdalam ilmu agama melalui berbagai media pembelajaran terutama melalui youtube karena Informan belum bisa untuk terbuka mengakui perbuatannya kepada orang-orang yang ahli dalam bidang keagamaan.

Informan dengan sendirinya mempelajari ilmu agama Islam dan mulai menerapkannya dalam kehidupan sehar-hari. Darisana lah semua Informan mulai merasakan ketenangan batin dan pikiran karena selalu berusaha mendekatkan diri kepada Allah SWT dan mulai menjauh bahkan sudah tidak berhubungan lagi dengan orang-orang yang memiliki kepribadian yang sama, karena Informan berpendapat dan berpandangan jikalau Informan terus berada dalam lingkungan orang-orang yang memiliki kecenderungan homoseksual maka bukan tidak mungkin untuk kembali kepada jalan yang dulu pernah dilaluinya.

Maka dengan adanya fakta tersebut peneliti dapat menyimpulkan bahwasannya Informan sebenarnya mengetahui dan sadar akan larangan tentang perilaku homoseksual dalam agama Islam. Tetapi karena sebelumnya masih belum bisa untuk meretas jalan hijrah maka Informan masih senang melakukan perbuatannya. Dan seiring berjalannya waktu dan bertambahnya pengetahuan Informan terhadap pemahaman keagamaannya maka Informan mulai meninggalkan perilaku homoseksualnya dan mulai meretas jalan hijrah. Yaitu dengan mulai mendengarkan kajian-kajian keislaman melalui media internet seperti youtube, instagram dan lain sebagainya.

Dengan terbentuknya akhlak yang baik maka akan berimplikasi terhadap perilaku dari seseorang begitu pula secara implisit individu yang memiliki penyimpangan orientasi seksual akan mampu tercegah dengan sendirinya karena akan selalu ada penolakan dalam dirinya jikalau melakukan hal-hal yang bersinggungan dengan aturan agama. Adapun upaya prepentif atau upaya pencegahan teraktualisasikannya perilaku homoseksual atau gay ini dapat ditempuh dengan cara:

Pertama, Menyadari bahwa perilaku homoseksual merupakan suatu hal yang dilarang dan diharamkan oleh Allah Swt. Dengan menyadari bahwa perilaku homoseksual merupakan suatu perbuatan yang keji dan diharamkan oleh Allah Swt maka seseorang yang memiliki kecenderungan perilaku homoseksual akan sedikit banyak untuk menghindari perilaku tersebut, karena memandang dengan melakukan perilaku tersebut akan merugikan dirinya sendiri serta telah melanggar larangan Allah Swt. Oleh sebab itu, penting sekali untuk memberikan pemahaman kepada para pelaku homoseksual mengenai larangan perilaku tersebut. Karena perilaku homoseksual ini merupakan suatu hal yang sulit untuk disembuhkan tetapi cenderung mudah untuk diatasi asalkan pelaku mampu berkomitmen terhadap dirinya untuk bisa menghindari perilaku menyimpang ini didalam lubuk hatinya. Salah satu ayat yang menyinggung larangan dan pengharaman perilaku homoseksual ini yaitu terdapat dalam surat al-A'raf ayat 80 sampai dengan ayat 81 sebagai berikut: 


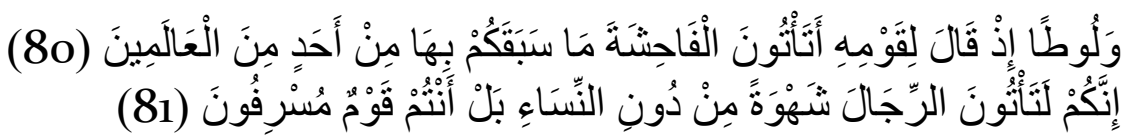

Artinya:

Dan (kami juga telah mengutus) Luth (kepada kaumnya). (Ingatlah) tatkala dia berkata kepada mereka, "mengapa kalian mengerjakan perbuatan fahisyah itu yang belum pernah dikerjakan oleh seorang pun (di dunia ini) sebelum kalian?" sesungguhnya kalian mendatangi lelaki untuk melepaskan nafsu kalian (kepada mereka), bukan kepada wanita, bahkan kalian ini adalah kaum yang melampaui batas (Q.S. al-A'raf:80-81).

Dari ayat di atas dapat dipahami bahwasannya perilaku homoseksual merupakan suatu perbuatan keji yang tidak dapat dibenarkan dari sudut pandang manapun. Oleh karena itu, sebagai manusia harus mampu berpikir dengan logis bahwasannya Allah Swt dengan tegas telah menerangkan dalam firman-Nya haram untuk memiliki perilaku tersebut apalagi melakukan perilaku tercela tersebut.

Kedua, Meninggalkan semua pergaulan yang berhubungan dengan perilaku homoseksual merupakan jalan yang sangat efektif untuk mengatasi pergaulan homoseksual yang cenderung melakukan hal-hal negatif dalam pergaulannya. Karena dengan meninggalkan pergaulan homoseksual seseorang yang memiliki perilaku ini akan mendapatkan langkah pencegahan untuk melakukan perbuatan keji ini kembali. Dengan cara meninggalkan pergaulan ini maka para pelaku homoseksual harus bisa merubah pergaulannya dan interaksinya dengan orangorang shalih yang selalu mengarahkan kedalam kebaikan dan nilai-nilai positif dalam menjalankan kehidupannya.

Ketiga, Menyadari tentang bahaya melakukan perbuatan homoseksual merupakan salah satu hal yang dapat menjadi jalan untuk mencegah dan mengatasi pergaulan homoseksual. Dengan menyadari akan bahayanya perbuatan homoseksual ini individu gay akan tersadarkan bahwa perilaku menyimpang ini sangat merugikan dirinya. Bahaya yang ditimbulkan dari perilaku homoseksual ini sangatlah kompleks karena menyangkut beberapa aspek baik aspek jasmani ataupun rohani seorang individu gay. Perbuatan ini dapat mempengaruhi pola hidup seseorang karena banyak sekali Informan yang ditemui oleh peneliti mengalami kasus ini yaitu adanya gangguan kecemasan yang berlebihan, merasa bersalah yang tak berkesudahan serta kehidupan yang tidak karuan, selain itu juga mengganggu akan kesehatan seseorang dikarenakan pola hidup yang tidak benar dan objek orientasi seksual yang tidak lazim dilakukan. Dengan melakukan sex anal serta berganti-ganti pasangan dalam melakukannya maka tidak menutup kemungkinan berbagai macam penyakit berbahaya akan selalu mengintai bagi pelakunya.

Keempat, Memberikan bimbingan konseling pemahaman keislaman merupakan suatu hal yang wajib diberikan kepada para pelaku homoseksual karena dipandang dapat memberikan solusi yang cukup efektif dalam mengatasi dan mencegah timbulnya perilaku ini. Didalam proses konseling ini akan digali lebih dalam apa yang dibutuhkan oleh orang yang akan diberikan konseling oleg konselor yaitu pelaku homoseksual atau gay itu sendiri. Bimbingan konseling pemahaman 
keislaman merupakan suatu hal yang sangat krusial untuk diberikan kepada para pelaku homoseksual dalam mengatasi perilakunya, karena bimbingan konseling merupakan suatu proses bantuan atau pemberian pertolongan kepada para pelaku homoseksual atau kumpulan individu para penderita homoseksual agar bisa terhindar dan dapat mengatasi semua permasalahan-permasalahan serta kesulitan yang melanda kehidupannya dengan tujuan untuk mencapai kebahagiaan hidup para pelaku homoseksual dan dapat keluar dari perilakunya tersebut.

Menurut Zakiyah Darajat yang dkutif oleh Rizqi Rahayu pendidikan agama Islam merupakan suatu proses bimbingan dan pengajaran kepada seseorang untuk dapat memahami dan mengamalkan ajaran agama Islam secara komprehensif dan menjadikan syariat Islam sebagai landasan dan pandangan hidup seseorang dalam menjalankan proses kehidupannya. Pendidikan agama Islam juga berorientasi untuk mengembangkan kemampuan seseorang dalam memahami, menghayati serta mengimani setiap ajaran yang telah ditentukan agar mendapatkan kebahagiaan hidup baik di dunia atau pun kelak di akhirat (Rahayu 2019).

Adapun upaya penyembuhan atau upaya kuratif yang dapat ditempuh dalam mengatasi perilaku homoseksual atau gay yaitu dengan cara:

Pertama, ruqyah syar'iyyah yaitu merupakan suatu metode penyembuhan suatu penyakit tertentu dalam hal ini perilaku homoseksual dengan menggunakan media bacaan ayat-ayat suci al-Qur'an dan al-Hadits atau do'a-do'a tertentu yang telah di contohkan oleh Rasulullah Saw (Al-indunissy 2014). Ruqyah merupakan suatu alternatif pengobatan non medis yang banyak digunakan oleh para terapis Islam karena metode ini sudah ada sejak lama bahkan Rasulullah pun mencontohkannya. Metode penyembuhan penyakit dalam pengobatan ruqyah yaitu menggunakan bacaan-bacaan al-Qur'an atau pun doa'do'a, pada dasarnya setiap ayat dalam al-Qur'an bisa di gunakan untuk metode pengobatan ini karena al-Qur'an merupakan as-syifa atau obat penawar bagi setiap penyakit dan masalah yang ada. Beberapa ayat al-Qur'an yang menjelaskan dan menjadi landasan sebagai obat atau tindakan ruqyah yaitu terdapat dalam surat al-Isro ayat 82 dan al-Fushilat ayat 44 sebagi berikut:

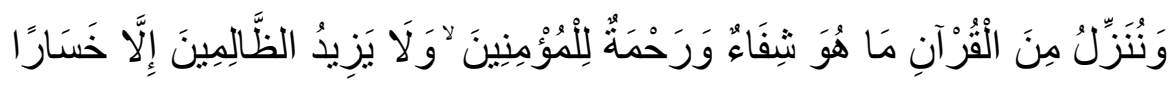

Artinya:

Dan kami turunkan dari al-Qur'an suatu yang menjadi penawar dan rahmat bagi orang-orang yang beriman dan al-Qur'an itu tidaklah menambah kepada orang-orang yang zalim selain merugikan (Q.S. al-Isro:82).

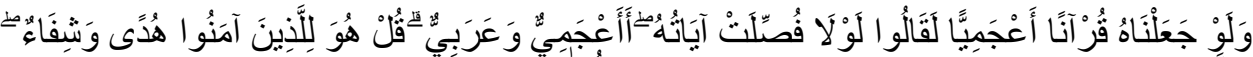

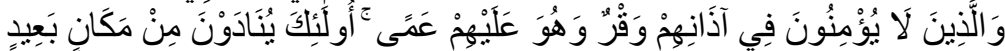

Artinya:

Dan jikalau kami jadikan al-Qur'an itu suatu bacaan dalam bahasa selain Arab, tentulah mereka mengatakan: "Mengapa tidak dijelaskan ayat-ayatnya?" 
Apakah (patut al-Qur'an) dalam bahasa asing sedang (rasul adalah orang) Arab? Katakanlah: "al-Qur'an itu adalah petunjuk dan penawar bagi orangorang mukmin. Dan orang-orang yang tidak beriman pada telingan mereka ada sumbatan, sedang al-Qur'an itu suatu kegelapan bagi mereka. Mereka itu adalah (seperti) yang dipanggil dari tempat yang jauh (Q.S. al-Fushilat:44).

Dari kedua penggelan ayat al-Qur'an tersebut membuktikan bahwa al-Qur'an dapat digunakan sebagai media penyembuhan berbagai penyakit dan masalah yang melanda setiap manusia. Begitupun dengan para kaum homoseksual yang ingin bisa sembuh dari perilaku homoseksualnya dapat menggunakan metode ruqyah ini sebagai salah satu jalan penyembuhan bagi masalah atau penyakit penyimpangannya tersebut.

Oleh karena itu, ruqyah merupakan salah satu jalan yang dapat ditempuh bagi para pelaku atau yang mempunyai perilaku homoseksual agar bisa sembuh dari perilaku penyimpangan seksual tersebut. Tetapi ruqyah juga bukanlah jalan satusatunya yang bisa menyembuhkan individu yang memiliki kecenderungan homoseksual tersebut tetapi aspek keyakinan diri dan keinginan untuk bisa sembuh dari diri pelaku homoseksual lah yang dapat menyembuhkan perilakunya itu.

Kedua, Upaya kuratif yang selanjutnya untuk dapat mengatasi perilaku homoseksual atau gay ini yaitu dengan cara senantiasa melaksanakan riyadhah ibadah. Riyadhah ibadah merupakan suatu bentuk latihan untuk membiasakan diri seorang individu dalam melaksanakan ibadah baik ibadah mahdah atau ibadah ghairu mahdah. Sehingga, kedua jenis ibadah tersebut pada akhirnya akan menjadi sebuah kebiasaan hidup seorang individu dalam menjalankan kehidupan sehari-hari dan menjadi sebuah kenikmatan dan menjadi suatu kebiasaan positif sebagi suatu bentuk perwujudan pengabdian kepada Allah Swt. Seseorang yang beribadah kepada Allah mereka akan senantiasa patuh dan tunduk kepada kehendak dan patuh terhadap aturan agama dan Tuhannya, sama halnya ketika seseorang tersebut suka atau tidak suka terhadap perkara yang telah ditetapkan oleh Allah Swt dan telah menjadi kehendak orang tersebut akan senantiasa mencintai Allah Swt dan RasuNya lebih dari apapun.

Seseorang yang memperhambakan dirinya atau senantiasa beribadah kepada Allah akan senantiasa patuh dan tunduk kepada kehendak dan aturan Tuhannya. Sama hal nya ketika seorang pelaku homoseksual atau orang yang memiliki perilaku gay jikalau ingin bisa mengatasi permasalahan terkait kesalahan dirinya maka hendaklah senantiasa menghambakan diri sepenuhnya kepada Allah Swt dengan cara senantiasa melaksanakan ibadah secara rutin tanpa terputus, agar timbul dalam dirinya rasa takut jikalau tetap melakukan perilaku yang selama ini diperbuatnya.

Ibadah juga bisa dijadikan sebagai sarana terapi dan relaksasi bagi jiwa yang kosong dan juga dapat dijadikan sebagai obat penawar bagi orang-orang yang penuh dengan kegelisahan. Salah satu ibadah yang dapat digunakan sebagai media relaksasi bagi seseorang ada shalat. Shalat adalah suatu kegiatan fisik-mental spiritual yang memberikan makna bagi hubungan antara seorang muslim dengan Allah, dengan sesama manusia maupun diri sendiri. Selain itu shalat juga diartikan sebagai suatu 
ibadah yang tersusun dari beberapa perkataan dan beberapa perbuatan yang dimulai dengan takbir dan di sudahi dengan salam menurut beberapa syarat yang tertentu. Lebih daripada itu, dengan shalat Allah Swt merealisasikan kasih sayang-Nya pada manusia agar mereka hidup dengan penuh kebahagiaan. Karena shalat akan menjadi sumber kedamaian hati bagi setiap insan yang melaksanakannya dengan khusyu penuh khidmat dan semata-mata karena Allah Swt. Selain itu hal terakhir yang harus dilakukan oleh para pelaku homoseksual atau gay agar dapat mengatasi masalah terkait orientasi seksual dan segala macam perbuatan yang telah dilakukan maka individu gay tersebut harus bertaubat dengan sebenar-benarnya taubat dan menyesali setiap kesalahan hidupnya agar mendapatkan ampunan dan pertolongan Allah Swt agar bisa di sembuhkan dari perilakunya tersebut dan juga dibarengi dengan berdo'a secara khusyu dan meminta pertolongan kepada Allah Swt agar terhindar dan terbebas dari perilaku menyimpang tersebut (Ardani 2008).

\section{Simpulan}

Berdasarkan hasil uraian penelitian di atas maka dapat disimpulkan bahwasannya upaya prepentif atau sebagai suatu tindakan pencegahan maka Informan dalam hal ini berusaha merubah perilakunya tersebut dengan cara menjaga diri seperti menjaga pandangan terhadap obyek seksual yang disenanginya, berusaha menutup dan menjaga auratnya sesuai dengan ajaran Islam yang telah ditentukan karena dengan terbukanya aurat tersebut akan menimbulkan syahwat dan fantasi seksual yang bisa menimbulkan tindakan seksual, selain itu Informan juga harus berusaha bergaul dengan orang-orang shalih dan menghindari perilaku menyendiri dikarenakan sesuai dengan yang diungkapkan oleh Informan bahwa ketika mereka sendiri akan selalu terbayang-bayangi untuk melakukan tindakan menyimpang tersebut, dan juga harus menyadari bahwasannya perilaku homoseksual atay gay merupakan suatu perbuatan dosa besar yang dapat menimbulkan suatu efek negatif terhadap individu gay tersebut. Melakukan bimbingan konseling pemaham keislaman juga salah satu cara yang dapat ditempuh untuk bisa mencegah perbuatan homoseksual atau gay ini karena dengan melakukan bimbingan konseling keislaman seorang gay atau Informan dalam hal ini dapat merubah pola pikir serta akan menyehatkan jasmani dan rohaninya terutama mental dari Informan.

Adapun upaya kuratif atau suatu tindakan penyembuhan dalam mengatasi perilaku homoseksual yang dapat ditempuh yaitu dengan cara berdo'a kepada Allah Swt agar bisa di sembuhkan dari dimilikinya perilaku homoseksual atau gay tersebut dan memohon penjagaan agar senantiasa dijaga dan dijauhkan agar tidak melakukan hal negatif tersebut dan juga dengan cara bertaubat dengan sepenuh hati dan penuh penyesalan karena telah melanggar aturan Allah Swt dengan cara melakukan perbuatan homoseksual. Jalan yang dapat ditempuh selanjutnya yaitu dengan cara melakukan ruqyah syar'iyyah karena dengan cara tersebut diharapkan mampu merubah dan menyentuh qalbu para pelaku homoseksual agar dapat sembuh dan tidak dimilikinya lagi perilaku menyimpang tersebut serta dengan cara melakukan psikoterapi agama dan juga melakukan riyadhah ibadah yaitu dengan senantiasa 
menjalankan ritual ibadah yang dapat menimbulkan gairah positif dalam menjalankan kehidupan agar bisa hidup normal dalam menjalankan nafsu seksualnya hal tersebut dapat ditempuh dengan cara menjalankan shalat lima waktu setiap hari dan berusaha berpuasa sebagai tameng untuk tidak terlampiaskannya tindakan buruk dan senantiasa menjalankan ibadah sunnah yang telah di contohkan oleh Rasulullah Saw.

\section{DAFTAR PUSTAKA}

Alase, Abayomi. "The Interpretative Phenomenological Analysis (IPA): A Guide to a Good Qualitative Research Approach." International Journal of Education \& Literacy Studies, 2017: 1213.

Al-indunissy, Nuruddin. Tutoriyal Ruqyah Mandiri. Sukabumi: Rehab Hati, 2014.

Ardani, Tristiadi Ardi. Psikiatri Islam. Malang: UIN Malang Press, 2008.

Baihaqi, Wildan. Psikologi Agama. Bandung, 2018.

Crider, Andrew B. Psychology. Glenview: Foresman and Company, 1983.

Dermawan, Abdurrafi Maududi. "Sebab, Akibat Dan Terapi Pelaku Homoseksual." Raheema: Jurnal Studi Gender dan Anak, 2016: 3.

Okdinata. Religiusitas kaum homoseks. Yogyakarta: UIN Sunan Kalijaga , 2009.

Rahayu, Rizqi. "Peran Guru PAI, Wali Kelas dan Konselor BK dalam Pembinaan Perilaku Keberagamaan dan Dampaknya Terhadap Akhlak Siswa." Attulab Islamic Religion Teaching and Learning, 2019: 3.

Sugiyono. Metode Penelitian Pendidikan Pendekatan Kualitatif, Kuantitatif dan R\&D. Bandung: Alfabeta, 2017. 